\title{
A comunidade do livro: a literatura, a diferença e a política da amizade
}

\author{
Antonio Barros de Brito Junior ${ }^{a}$
}

\begin{abstract}
Resumo
Este artigo interroga o conceito de amizade e seu envolvimento com a filosofia politica e a literatura. Passando pelos pensamentos de Aristóteles e de Hannah Arendt, o texto reflete, em primeiro lugar, sobre a filosofia politica voltada para o consenso em prol de uma visão universalista, mostrando como emerge a diferença amigo-inimigo na centralidade do logos político. Depois, o texto desemboca nas reflexões de Jacques Derrida, presentes sobretudo no livro Politiques de l'amitié, momento no qual a linguagem e a noção de diferença são consideradas do ponto de vista das aporias presentes na relação entre a amizade e a politica. Por fim, este trabalho especula sobre o modo pelo qual a literatura pode ser um dos locais onde reside a política da amizade.
\end{abstract}

Palavras-chave: Políticas da amizade, Jacques Derrida, Diferença, Desconstrução. 
Começo por um clichê: “Ler um livro é para o bom leitor conhecer a pessoa e o modo de pensar de alguém que lhe é estranho. É procurar compreendê-lo e, sempre que possível, fazer dele um amigo", afirmou Hermann Hesse. Há quem diga que no clichê há sempre uma lição, mesmo que seja um conhecimento prático ou senso-comum. Neste caso, trata-se de considerar leitor e autor como membros de uma relação mediada pelo livro, na qual o estranho se aproxima do que é familiar lhe "falando ao coração" e conquistando sua simpatia, carinho e respeito - todos aqueles afetos típicos da philia. Entre um e outro instaura-se uma espécie de "congenialidade" amistosa, que transita pela escritura. Dá-se, aí, uma aritmética simples: a unidade (leitor) faz-se dobro (leitor e autor), numa projeção microscópica, porém embrionária, de uma comunidade por vir. Comunidade do livro? No livro? Mas, antes do livro, onde está a comunidade? E a amizade?

A presunção de amizade pela escritura - e, fundamentalmente, pela linguagem - é um dos elementos que perpassa a filosofia política dos primórdios até nosso século. Não se trata de especular sobre uma amizade interesseira, mas, pelo contrário, seguindo as lições que vêm do Estagirita, trata-se de fundamentar um Estado e toda uma sociedade através da amizade. Já o livro VIII da Ética a Nicômaco não deixa dúvidas ao dizer que "[...] a amizade parece ser o vínculo que une o Estado; e os legisladores parecem mais zelar por ela do que pela justiça, uma vez que promover a concórdia, que se afigura aparentada à amizade, constitui o principal objetivo deles [...]" (ARISTÓTELES, 2007, p. 236).

Esse tipo de amizade - que dispensa um "suplemento" de justiça, dado que é, por si só, justa -, é, no entender de Aristóteles, a mais rara de todas, não só porque envolve o prazer e a utilidade que marcam as amizades banais, mas também porque envolve indivíduos do mesmo ethos. A proporção de afetos dados e recebidos é idêntica para ambas as partes, e a amizade é duradoura e sobrevive à distância exatamente porque entre semelhantes há uma predisposição para se conservar a justa medida, essencial para a verdadeira philia. Qualquer outra relação é por natureza assimétrica (entre pai e filho, marido e esposa, velho e jovem - advoga Aristóteles), culminando, portanto, numa "desproporção" do 
afeto, que resulta em um prazer ou uma utilidade necessários apenas para os indivíduos, porém nunca para o Estado.

Mas como um Estado que repousa sobre esse tipo de amizade pode se erguer sem o auxílio dos signos legítimos da reciprocidade? A aposta de Aristóteles em uma regularidade do ethos humano - ou o ritmo, no sentido que Agamben (1994) dá a essa noção - pode ser uma salvaguarda. Contudo, quando envolvemos toda a prática da amizade em uma filosofia da linguagem, fazendo-a passar inclusive pelo livro, talvez a possibilidade de uma sociedade amparada na amizade seja uma verdadeira quimera. Afinal, não foi o próprio Aristóteles quem dissera "Oh!, meus amigos, não existe nenhum amigo", ${ }^{1}$ numa formulação aporética que apela ao amigo para esconjurá-lo em seguida?

É sabido que a amizade - o amor (philia) de um para com o outro, escorado no sentimento mútuo de admiração e cuidado, que não se confunde com o outro amor (Eros) nutre-se da confirmação do sentimento não apenas através dos afetos, mas também da constância das atitudes e da regularidade do pensamento, mediante práticas simbólicas socialmente marcadas - práticas que, no limite, se leem como "textos". ${ }^{2}$ A comunidade formada na amizade é aquela que "captura" o amigo na própria nomeação: o amigo não existe em si, fora da atitude propriamente doadora da philia, mas tão-somente quando alguém voluntariamente aceita outrem como "amigo(a)". Agamben (2005) está certo ao remeter o conceito de amizade a algo que é existencial, antes mesmo de ser conceitual. Para o filósofo italiano, a aisthesis da existência que comporta, já na visão de Aristóteles, um elemento poético forte, no sentido de uma sensação de vida que vibra a cada ação prática do indivíduo - encontra na presença do amigo uma espécie de com-sentir (com-sentimento), um prazer no existir-em-comum, que faz com que o amigo se apresente como uma espécie de alter ego. A convivência com o amigo traduz-se, assim, em uma comunhão de ideias e sentimentos que torna possível, em última análise, a transcendência do individual para a comunidade desdobrada, do singular ao plural.

Ora, tal pluralidade, formada no prazer do com-sentir, é,

${ }^{1}$ Todas as notas no fim do texto. 
segundo a qual a política, enquanto um espaço público formado na esfera da ação dos indivíduos, não prescinde da razão $(\log o s)$ como forma de promover o entendimento mútuo. Na esfera pública da polis grega, portanto, o sujeito livre detém a linguagem ou logos (e não são todos: mulheres e escravos compreendem o logos, mas não o detêm) e age no intuito de influenciar a comunidade, buscando o consenso (daí inclusive a importância de uma techné rhetoriké para o benefício da polis). Assim, a amizade já aparece subjugada por uma determinação de um pensamento, de um saber, que fundamentalmente institui o amigo (aquele que detém o logos) e que recolhe na linguagem e na produção de uma razão compartilhada ou consentida a prova da amizade.

Vê-se, portanto, que, desde o princípio, essa política que nos serve de modelo surge a partir de uma articulação de uma diferença primordial: entre o amigo e o não-amigo (muitas vezes, o inimigo) há um sentimento que costura os laços de uma possível comunidade, sem a qual não há, sequer, o entendimento da decisão consentida. O passar dos séculos não nos fará perder essa ideia. Na obra de Hannah Arendt, por exemplo, podemos encontrar uma formulação filosófica mais atual dessa concepção. Na transição de uma tradição política do passado para o presente, Arendt concebeu uma teoria política que se inspira na visão de que o político é uma esfera de atuação livre decorrente da ação prática do ser-humano. Assim, a política, enquanto exercício de poder, de soberania, de voto, de opinião, de juízo etc., faz-se dentro de um espaço heterogêneo. Logo, a política tem que lidar, em última análise, com a diferença. Em que isso acarreta?

Com efeito, a diferença é um problema ontológico, e, no que diz respeito à sua articulação com a filosofia política, temos pelo menos dois cenários: de um lado, a diferença procede de uma distinção ontológica que marca um "próprio da humanidade" (de modo que podemos nos referir ao serhumano como um "animal político"); de outro lado, a diferença instaura uma abertura existencial para o próprio ser-humano no campo das interações e das performances sociais. Com Arendt (e a tradição logocêntrica da qual sua filosofia política é - para o bem ou para o mal - partidária), a diferença tem que ser pensada mais no segundo viés, isto é, no sentido de uma singularidade que se constrói politicamente (para Arendt 
não existe um homo politicus), justamente porque a produção e a administração da vida na esfera pública dependem de uma relação que se dá no interstício das performances individuais, das particularidades de opinião e juízo. Cada indivíduo é singular, mas, como tal, faz parte de um todo que forma a pluralidade de opiniões e práticas. ${ }^{3}$

Porém, a singularidade parece se esvair na medida em que, na visão arendtiana, a noção de juízo ganha destaque, com o salutar (porém, a meu ver, ingênuo) intuito de que possa haver no campo do político alguma abertura para o debate que, ulteriormente, resultará em consenso. Na verdade, o reconhecimento de que o político se dá no interstício das relações humanas deixa claro que a política também diz respeito ao modo como os sujeitos persuadem uns aos outros sobre aquilo que deve ser executado na prática. Não é uma questão de presumir o ponto de vista universal em detrimento da singularidade; trata-se, com efeito, de uma possibilidade formal e concreta de conformidade de juízos a fins práticos e, quando mesmo, à representação (no sentido kantiano) do mundo - ou seja, a busca pelo consenso (ou com-senso). Arendt parece partir da noção relativamente logocêntrica segundo a qual o particular da experiência se conforma ao universal dos parâmetros de julgamento estabelecidos. Assim, a singularidade mesma dá lugar a uma comunidade subsumida, ainda que meramente no nível semântico-pragmático em que se formam e se consolidam os juízos. Ojuízo de um determinado sujeito, na medida em que o sujeito ocupa a posição na esfera pública, pode e deve ser pensado como um juízo universal - ou que tem a possibilidade de se alçar como um juízo universal, cujo "[...] único pré-requisito é a faculdade de julgar, o que tem muito mais a ver com a capacidade humana de discernir do que com a de organizar e subordinar" (ARENDT, 2008, p. 154-155). Se o sujeito fosse essa singularidade absolutamente radical, nenhum juízo poderia atingir esse grau de conformidade com o universal, dado que estaríamos falando de uma experiência tão particular, que nenhuma ocasião haveria para o entendimento mútuo. ${ }^{4}$

Human plurality, the basic condition of both action and speech, has the twofold character of equality and distinction. If men were note equal, they could neither understand each 
other and those who came before them nor plan for the future and foresee the needs of those who will come after them. If men were not distinct, each human being distinguished from any other who is, or will ever be, they would need neither speech nor action to make themselves understood (ARENDT, 1958, p. 175-176).

No limite, a política deve agir sempre com fins a manter aberta essa possibilidade de agir livremente com o intuito de manter viva a liberdade de ação, de pensamento e de fala, pois só assim pode haver o livre consenso. Em regimes e governos de exceção, a liberdade é suprimida e a possibilidade do consenso deliberado dá lugar ao consenso extorquido. Nesse sentido, o significado do político é, para Arendt, a resistência ao mal, tal como um imperativo categórico ético que funciona como um consenso a priori (ou um a priori do consenso, o que dá quase no mesmo), um com-sentimento que afugenta o mal e a aniquilação da esfera pública, realizado no amor mundi.

Com isso, a diferença ontológica não pode ser pensada em si, mas apenas no regime ético-estético-poético de uma existência já prevista e integrada no sistema social simbólico que fornece as competências e as performances aceitas para a atestação de si como sujeito político na esfera pública. ${ }^{5} \mathrm{E}$, na verdade, a consolidação dessa esfera pública depende sobremodo da amizade: quando a política é ameaçada pela aniquilação, seja pela ascensão do totalitarismo, seja pela hecatombe nuclear, o ser-humano se vê presa de um recolhimento ou alienação que o privam do contato efetivo com o seu semelhante. Diante dessa ameaça, apenas a amizade e a solidariedade podem, de fato, retirar o sujeito da solidão existencial radicalizada no contexto de perda da esfera pública. $O$ cuidado de si mostra-se inclusive na responsabilidade para com o outro: responsabilidade mantida no prazer, no desejo, no convívio livre, mantendo vivas as capacidades de agir e pensar no âmbito verdadeiramente político.

Mas a política que se enraíza na amizade está a salvo do engodo (a amizade interesseira) e da falha (o afeto extraviado)? Em que circunstâncias ela é possível, afinal? Lançadas contra a longa tradição política ocidental, essas questões encontram algumas respostas nas colocações de Derrida no livro Politiques de l'amitié (DERRIDA, 1994), que jogam luz sobre as aporias da imbricação da política com a amizade e com a linguagem. 
Resgatando, primeiramente, o sentido filosófico da amizade e, em seguida, repensando o estatuto da diferença, talvez seja possível repensar a conformação da comunidade política em outros termos que não aqueles da razão comunicativa. E, curiosamente ou não, o que vamos encontrar no percurso é uma reflexão sobre o estatuto do signo que, não raro, remete à escritura e, consequentemente, ao universo da literatura. Por isso, tomo o mesmo ponto de partida de Derrida, que, como não poderia deixar de ser, é o aforismo aristotélico "Oh!, meus amigos, não existe nenhum amigo" - no qual essas questões estão colocadas, na visão do filósofo franco-argelino.

Oque é a amizade e o que é e onde está o amigo? Ao propor essas questões, Derrida percebe que um dos fundamentos da amizade está na constância. $\mathrm{O}$ amigo se torna verdadeiramente amigo quando exibe os caracteres da amizade e permanece fiel no amor e no sentimento, mas também na justiça, no segredo guardado, na promessa mantida etc. A constância, todavia, mede-se apenas com base em sinais, logo numa "aparência" de constância que não pode nunca ser reduzida ao ideal da constância (e, logo, da amizade). Dito de outro modo, e tomando emprestada a noção de amor, quem ama sabe que ama e a quem ama, mas quem é amado só pode imaginar, suspeitar ou crer que é amado. Logo, a percepção e a certeza do amor ao outro são de um grau diferente da percepção e da certeza do amor do outro, de modo que, no limite, parafraseando Aristóteles, "nenhum amigo é possível" justamente porque a amizade não é possível fora da própria interrogação de outrem.

Ora, a ausência de uma garantia no sentimento abre espaço para a outra face da amizade. Uma vez que necessita da manutenção do caráter do amigo, e uma vez que esse caráter se interpreta mediante as ações e os discursos tanto na esfera íntima quanto na esfera pública, a amizade mostra-se como algo frágil. Nesse mesmo lugar abriga-se também o inimigo. Mas este não é o inverso absoluto do amigo. De fato, no interesse da amizade está, também, o interesse na inimizade, dentro de uma visão aporética que o pensamento derridiano sabe captar. $\mathrm{O}$ que reúne o indivíduo em torno do querer bem ao outro, sendo um sentimento próprio de quem acolhe o próximo, dá chance, efetivamente, de um sentimento de repulsa ou de recusa de um outro mais além e sequer nomeado. Assim, no seio da amizade se introduz a inimizade: na medida em que a amizade 
pressupõe a aliança, o segredo, o afeto e a afinidade - enfim o cuidado do/com o amigo -, ela se torna, por isso mesmo, algo em prol de um e em detrimento de outro(s). Ocuidado do amigo se mantém vigilante, e, quando o amigo se põe em perigo (ou seu interesse, em risco), o socorro prestado permite a irrupção da inimizade com quem o ameaça. Recorta-se aí um espaço de conflito em que o próprio inimigo surge da amizade. E mais: o próprio amigo, faltando com a constância, tende a ser aquele que, por isso, cai na falta e/ou na falha, tornando-se o inimigo da vez. Ou ainda: o inimigo, na medida em que está sempre aquém da amizade, é, por isso, mais constante que o amigo. No desprezo recíproco (e em alguns casos no interesse recíproco da aniquilação), há uma constância que aproxima os conceitos de inimigo e de amigo, e a constância é algo que curiosamente se encontra apenas nas marcas legíveis da inimizade. Finalmente: o inimigo se disfarça, assume o papel do amigo, e, assim, finge o afeto que cumpre o dever do amigo, colocando-se à vontade no espaço vazio da amizade.

Les deux concepts (ami/ennemi) se croisent dès lors et ne cessent plus de s'échanger. Ils s'entrelacent, comme s'ils s'aimaient l'un l'autre, le long d'une hyperbole en spirale : l'ennemi declare [...], l'ennemi vrai, voilà un meilleur ami que l'ami. Car s'il peut me haïr ou me faire la guerre au nom de l'amitié, for Friendships sake, par amitié pour l'amitié, par amour de l'amitié, s'il respecte en somme le vrai nom de l'amitié, il respectera mon propre nom. Il entendra ce que celui-ci devrait, même s'il ne le fait pas, nommer proprement, la singularité irremplaçable qui le porte et vers laquelle l'ennemi alors se porte ou se réfère. S'il entend mon ordre, il s'adresse à moi, à moi-même, il me respecte, à distance de haine, moi au-delà de moi, de ma conscience même. Et s'il veut ma mort, du moins la veut-il, peut-être, lui, la mienne, singulièrement (DERRIDA, 1994, p. 91, destaques do autor).

$\mathrm{Na}$ ascensão da amizade como fundamento da comunidade temos, portanto, uma zona indistinta, precária, que separa o amigo do inimigo, ou que pode transformar o inimigo em amigo e vice-versa. Muitas ações "políticas" foram feitas, inclusive, a partir do pressuposto de que a política, orientada pela guerra, consistia na aliança com o amigo e no combate ao inimigo: política por fins da amizade, sem gratuidade, no interesse da soberania, mas sempre com base na extensão da amizade à comunidade, da afinidade que cria 
o espaço do próprio e do alheio, do nacional e do estrangeiro, do masculino e do feminino, através da philia - binômios que, como prontamente se percebe, transitam livremente pelo campo epistêmico do estudo da literatura.

De qualquer modo, capta-se, aí, o verdadeiro sentido da diferença a que a filosofia política se abria desde o princípio: "amigo" e "inimigo" ("amigo" ou "inimigo") são, no fundo, apenas significantes que, no traçado de sua polarização, carregam consigo modos de ser, razões, afetos, enfim, uma gama de elementos que os distingue por força da diferenciação, mas que, no horizonte primeiro da própria significação, permaneciam ambíguos na sua diferensa (différance). ${ }^{6}$ Uma vez diferenciados, os significantes formarão parte da experiência do que é ou não é a amizade, e, com isso, darão os critérios de legibilidade da experiência política - e, por que não dizer também, literária.

Mas qual é a extensão dessa amizade - quanto dura e a quantos se dirige? O que nos leva à pergunta: qual a extensão da comunidade política? Se no âmbito pré-político a amizade se contabiliza pelo $1+1$, como estabelecer a amizade com o mais de um (>1), com uma comunidade política, a nação, o Estado, a pátria? Ora, se a amizade requer esse esforço de interpretação e dedicação ao outro, se ela aproxima o amigo e ao mesmo tempo produz o inimigo, então ninguém, individualmente, pode requerer uma amizade aritmeticamente infinita, senão uma amizade infinitamente duradoura. Aliás, como mostra Derrida, seguindo a lógica aristotélica, a amizade é verdadeiramente amizade porque é, no limite, rara: "não há amigos" também quer dizer que só pode haver apenas um amigo (nunca o plural). Desse modo, a ninguém é permitido estender a amizade para além de suas forças pessoais, o que significaria, em última análise, que nenhuma amizade é propriamente política, ou, melhor dizendo, que o político, na medida em que se projeta na pluralidade, não pode requerer o amigo, mas apenas a amizade. Isso equivale a dizer que:

(1) a amizade pré-política, fundacional, não pode ser o modelo do político se não dispensar o amigo e se orientar para a amizade enquanto forma (ou fórmula) de se fazer amigos. Mas, já aí, seriam esses amigos verdadeiramente amigos? Seria a amizade mais falível, porque menos dedicada, logo, mais propensa à inimizade? E qual deve ser a duração dessa 
amizade, no âmbito do acontecimento político que a funda? São problemas de difícil resolução, o que faz com que a amizade seja sempre um lugar vazio a ser preenchido pelo outro, um qualquer outro (o amigo desta hora, que pode não ser o da hora seguinte), que cairá fatalmente no indecidível amigo/inimigo;

(2) assim, a comunidade que se funda só pode ser erigida num tipo de amizade que já não é decididamente a philia, mas sim uma amizade que se desloca para outro campo, uma amizade que visa à justiça e ao reconhecimento, porém não põe em causa o amigo de fato, apenas a comunidade. Essa amizade, que praticamente se coloca como uma finalidade sem fim, não é de modo algum deplorável. Ela é um tipo de amizade abrangente, infinita não no tempo e no espaço da amizade com o mais próximo, mas sim no tempo e no espaço de uma amizade universal, uma amizade com a humanidade, por assim dizer - o principal modelo da democracia, de acordo com Derrida. Exatamente por isso, essa amizade é profundamente solitária, tal como a frase de Aristóteles em algum sentido sugere;

(3) em suma, uma amizade que não se limita à proximidade é, também, uma amizade que, por isso, é sem centro; é uma amizade "sistêmica", que irradia do um ao dois, do dois ao três, do três ao quatro e assim por diante, até completar-se no número ideal do infinito da amizade sem polémos, virtualmente sem inimigo (e, por isso mesmo, potencialmente propulsora da inimizade). Trata-se, enfim, de uma amizade que se dissolve no interesse da vida em comum e que, portanto, é sem verdadeira utilidade para o amigo de fato, mas essencial para a concretização da polis.

Em suma, talvez - e o talvez (peut-être) tem um peso gigantesco no livro de Derrida justamente por ser a marca desse indecidível que caracteriza o seu projeto desconstrucionista - a amizade seja mais solitária do que a princípio se estaria disposto a crer. A amizade, talvez, seja sem amigos: uma amizade carente de um amigo de fato em quem se possa acreditar infinitamente, e que pode efetivamente preencher o lugar vazio daquele que supostamente ama e quer bem. Trazendo o problema para o terreno da política, temos, então, que talvez, bem no limite, a comunidade que deve ser formada em torno da amizade é nada menos do que uma comunidade sem princípio e origem (arché), cuja força reside 
exatamente em não ser verdadeiramente amigável, mas, pelo contrário, aberta ao infinito de uma amizade sem fim nem circunstância, nunca perene, mas sempre provisória, feita e refeita na contingência do signo. Na passagem do um a um da amizade pré-política para a progressão aritmética que forma a comunidade (e o Estado, especialmente na democracia), amplia-se consideravelmente a exigência quanto ao nível de afeto, cuidado e responsabilidade, e também quanto ao nível de segurança e certeza da compreensão do signo, ao ponto em que o sentimento da amizade confunde-se mais com uma leve "camaradagem", ineficaz, portanto, no que diz respeito ao laço de confiança imprescindível para a amizade pré-política, mas ainda assim profícua para o amálgama da comunidade política. ${ }^{7}$ Assim, tem-se a impressão de que quanto mais se afasta das formas de governo baseadas na arché (oligarquia e aristocracia, por exemplo), a amizade política se assemelha menos com a amizade.

Contudo, o transbordamento dessa amizade afeta a contabilidade política. Na comunidade sem limites da democracia, essa amizade, que abre o espaço para a inimizade e o inimigo, quanto mais se expande, mais deixa um "resto", potencial ou calculável, que se coloca à margem da comunidade. É o inimigo do Estado que espreita de fora ou o inimigo que se abriga no seio da comunidade? Seja como for, pode-se ao menos supor que, quanto maior o número de amigos, maior o número de inimigos, o que instaura uma complicada aporia na filosofia política do consenso: o impulso da comunidade para o seu limite último (a humanidade?), na busca de um com-sentimento generalizado, é o perigoso impulso para o senso-comum sem contrário, que, quanto mais se efetiva, mais deixa um rastro do próprio apagamento - isto é, quanto mais tende ao universal, contraditoriamente mais exíguo vai ficando, despejando mais e mais seus restos pelo caminho (ou, no nível ontológico, suas "diferenças"). A cilada conceitual é, então, a seguinte: a amizade plural que fundaria a comunidade máxima do consenso só é possível mediante o abandono do verdadeiro amigo e a invocação de um espectro, um amigo que não tem rosto nem particularidade, mas que, em compensação, adquire status de amigo se se conforma ao universal pressuposto. Como um ciclo que se completa, o 
modelo do amigo se volta para os fundamentos naturais da amizade (família, pátria, Estado-nação), repetindo o gesto falogocêntrico da fundamentação na arché, que, entre outras coisas, privilegia a fraternidade (o amor do irmão, excluindo efetivamente a mulher), reforçando os laços sanguíneos ou os compromissos aristocráticos fundados no território.

Tout ce qui s'appelle ici démocratie (ou aristodémocratie) fonde le lien social, la communauté, l'égalité, l'amitié des frères, l'identification comme fraternisation, etc., dans le lien entre ce lien isonomique et le lien isogonique, le lien naturel entre nômos et phûsis, si l'on veut, le lien entre le politique et la consanguinité autochtonique. C'est aussi un lien entre un constat (théorique ou ontologique) et un engagement performatif (promesse, serment, fidélité aux ancêtres morts, etc.). Ce lien entre les deux liens, cette nécessité a priori synthétique, si on peut dire, noue ce qui est à ce qui doit être, il oblige, il rattache l'obligation au lien dit naturel de la naissance [...] (DERRIDA, 1994, p. 121, destaques do autor).

\title{
Ou valeria dizer:
}

\begin{abstract}
So, even the idea of democracy [...] had to agree with the presuppositions of this concept [friendship - amizade], with the privilege granted to man, to brotherhood. What does brotherhood mean? It means of course the family, the familial schema, filiation, it means brother instead of sister and there are a number of texts in which sister is simply a case of brother, no different, and it makes no difference. So, you have here all the conditions for the canonical definition of politics, of the state, the relation to autochthony in Greece, to the territory, the nation-state, filiation, representation, sovereignty, all these share this phallocentric concept of the social bond as friendship (DERRIDA e BENNINGTON, 1997).
\end{abstract}

Quer dizer que a própria linguagem na qual se efetiva a comunidade política parece ter algo a ver com as ideias derridianas acerca do monolinguismo (cf. DERRIDA, 1996). A questão emerge do âmago da frase de Aristóteles: estaria ela fazendo uma interpelação aos amigos (“Oh, amigos!”), ou estaria ela constatando algo sobre "aquele que tem amigos"? Para Derrida, na filigrana do texto grego escondem-se nuanças importantes que revelam o aspecto decisivo dessa comunidade e de sua edificação. Se a frase faz uso da apóstrofe para dizer que não há amigos, seja qual for o conteúdo semântico (irônico, que seja!) dessa proposição, resulta claro que quem fala se 
dirige a uma audiência concreta ou possível e, como tal, ao serem chamados de "amigos", os membros a quem se dirige essa frase são considerados na amizade. Ou seja: para que o enunciado possa funcionar, ele precisa interpelar aqueles que, depois, serão negados como amigos, mas interpelados como amigos íntimos, presentes, estando ali mesmo, na escuta dessa sentença, com-sentindo. E, assim sendo, esses amigos, para compreender que a frase lhes interpela, precisam pelo menos se pôr na condição de amigos - identificar-se como amigos dentro da língua do Outro - para enfim negar a amizade, assumindo o papel da indiferença ou inimizade. Isso mostra, então, que é primordialmente na linguagem que a amizade faz seus amigos, contingencial e precariamente. A linguagem forma, então, um espaço de circulação da ideia (do consenso, em última análise), que formata a possibilidade primeira e última da intercompreensão, da congenialidade. Embora depois venha rejeitar aquilo que ela produz, a língua faz valer esse espaço público onde, ainda que por pouco tempo, se estabelece a comunidade de amigos (logo, a comunidade política).

Mas outro fenômeno acontece: a frase, produzida uma vez num contexto, se reproduz noutro contexto, e essa iterabilidade ${ }^{8}$ faz com que outra vez se renove o sentido perdido dessa coletividade ou dessa comunidade espectral que fica sempre à espreita e que opera no intervalo de uma sentença. Com isso, a linguagem faz funcionar sempre e novamente essa comunidade (de falantes), que se entende mutuamente, que ajuíza na diferença, que age em torno da frase, que consegue, inclusive, negar o sentido da frase, concordando com o emitente mesmo quando, em princípio, ela já não é nem o amigo que a frase rejeita. Essa comunidade só se faz provisoriamente e negando a si mesma qualquer direito ao universal.

Portanto, no modelo de uma amizade na constância e de um "aprisionamento" do ser no conceito (amigo ou inimigo), existe, antes, a língua, que se coloca como o espaço, a instância da voz, da escuta do amigo, o mais próximo e o mais ausente, não para remediar conflitos e estabelecer a universalidade (como Arendt e Habermas parecem querer), mas simplesmente no caso de um com-sentimento, de uma amizade que já nem é amizade ainda, mas que é, para já, um lugar onde se poderá construir uma amizade, qualquer que seja. Nessa diferensa é que se abrange o universal da comunidade e a singularidade 
do sujeito que, sem amigos, proclama a solidão no espaço público de uma afinidade requisitada, precária e consistente. A linguagem (e, de certo modo, o livro, mais ao longe) acaba sendo, então, um elemento crucial para a produção do político, na medida em que traduz a amizade e carrega o testemunho do amigo, dá prova da constância necessária, instaura o indecidível entre o amigo e o inimigo e faz com que a diferensa se resolva na diferença linguística.

Talvez, então, a experiência política encontra na literatura um interessante paralelo - um paradigma, talvez. Retomando Hesse, se ler um livro é conhecer um estranho e dele se tornar um amigo, então a leitura também está na esfera política na qual a amizade se prova na clivagem do significante e da diferença. Ler um livro é com-sentir naquilo que ele oferece ao leitor; é interiorizar o Outro (o personagem, o autor) com base na experiência significante dessa singularidade. Primordialmente, o livro não me dá nem o amigo, nem o inimigo; ele é a diferensa mesma pela qual esses significantes são possíveis. Mas, na prova da amizade - quando o escritor que me dá aquilo que é em parte meu (ou seja, o "meu" amigo) -, o amigo já se fez, e, assim, ele se monumentaliza na exata medida em que a leitura se cristaliza no plano social e político. Em outros termos, o amigo recém-descoberto é levado com o leitor para a comunidade (potencial) de outros escritores-amigos. Com eles, o leitor forma um "grupo", uma "família", em que o significante "amigo", embaraçado com a subjetividade do leitor, fomenta uma genealogia. Daqui por diante, o leitor chamará de amigo o livro que comporta essa prova de amizade na constância da leitura, sobretudo porque o livro lhe dá apenas e tão-somente a mesma resposta: "Call me Ishmael..." another time! Nessa iterabilidade faz-se a comunidade possível que, em torno do(s) livro(s), designa os modos de ser amigo ou inimigo. Ela, a iterabilidade, pode promover, inclusive, os modos de ler e interrogar essa amizade, tratando como "amigo do amigo" aquele que lê no livro o mesmo que o leitor lê, contabilizando camaradas na recorrência e homogeneidade do comportamento face ao apelo "Oh, amigos...". Desnecessário dizer, portanto, que em torno do livro existe a possibilidade de edificação da Literatura (com L maiúsculo) - aquela instituição pedagógica, nacionalista, logocêntrica, aquela que não é diferensa, mas tãosomente presença, consenso, com-sentimento infinito no plano 
de uma amizade que se faz e desfaz depois da clivagem. E, no entanto, a verdade é que "não há nenhum amigo" porque a comunidade formada não alcança a totalidade, uma vez que na sua clivagem e pela própria potência do livro, ela gera o resíduo - a "horda inimiga" - que, não com-sentindo com a leitura "amiga", produz outra configuração do campo político das letras. Nesse sentido, a diferença volta a si na diferensa, e a comunidade política é novamente evocada no gesto solitário da leitura. "Call me Ishmael", once again, call me Ishmael you too... basta isso para que Ishmael, que no seu lugar entre as capas do livro não é nem amigo, nem inimigo, seja o inimigo da vez.

Portanto, a literatura também faz aparecer alguma comunidade, não pressuposta, sempre emergente, assinatura acontecimento contexto, compromisso e com-sentimento. Na solidão, o indivíduo é nada menos do que o eremita que se alberga numa comunidade que nunca vem (en demeure), mantendo-se livre para aceitar o outro, o qualquer outro ${ }^{9}$ (o inimigo?), que virá... talvez... da leitura. É o eremita que se alberga no livro e que encontra na escritura a opacidade de uma voz sem arché, mas que realiza para si a amizade, com comsentimento, mesmo a despeito de qualquer lógica fundante ou consenso arrancado da racionalidade comunicativa. Mas é também o amigo que encontra o amigo, o compatriota, o autóctone, na História da Literatura que incessantemente se escreve na herança do monolinguismo do Outro, que traça a linha divisória entre o dentro e o fora da leitura - do direito à interpretação e ao pertencimento à comunidade (de "verdadeiros" leitores).

Eis a aporética comunidade do livro, forjada, por um lado, na (des)leitura, na iteração do desvio, que - e apenas nessa condição - promove o afeto entre escritor e leitor, sem se prender a um sentido fixado, nem sequer o da própria amizade. Porque ler é, sempre, ler sozinho, sem o amigo do lado, ainda que o mantenha no horizonte. E, por outro lado, triunfo da amizade na letra que se instaura na diferensa da literatura, diferindo o sujeito que portará a palavra e dará o testemunho dessa comunidade em detrimento de qualquer outra. É a literatura que, no deslizamento incessante dos significantes, prevalece como o lugar dessa aporia; ou, mesmo, como o sintoma mais claro desse vazio significante que instaura, sem o apelo da Necessidade (necessité em oposição a besoin), a 
diferença pura ou "lugar do acontecimento da desconstrução" (SISCAR, 2012, p. 66), num indecidível que não apenas capta o sentido último de uma amizade política, mas que, talvez, permite também, como quer Hermann Hesse, que se produza primeiramente o amigo(1) e, depois, o amigo(2), o amigo(3), o amigo(4)... e o inimigo, talvez...

\section{REFERÊNCIAS}

AGAMBEN, Giorgio. "La amistad”, La Nación, 25 de setembro de 2005, http://www.lanacion.com.ar/741397-la-amistad.

AGAMBEN, Giorgio. L'uomo senza contenuto. Macerata: Quodlibet, 1994.

AGAMBEN, Giorgio. La comunità che viene. Turim: Einaudi, 1990. ANDERSON, Benedict. Comunidades imaginadas. Reflexões sobre a origem e a difusão do nacionalismo. Tradução de Denise Bottmann. São Paulo: Cia. das Letras, 2008.

ARENDT, Hannah. "Introdução na Política". In: ARENDT, Hannah. A promessa da política. Tradução de Pedro Jorgensen Jr. Rio de Janeiro: DIFEL, 2008.

ARENDT, Hannah. The Human Condition. Chicago e Londres: The University of Chicago Press, 1958: 175-176.

ARISTÓTELES. Ética a Nicômaco. Tradução de Edson Bini. Bauru: Edipro, 2007.

BADIOU, Alain. Abregé de metapolitique. Paris: Éditions du Seuil, 1998.

DELEUZE, Gilles. Diferença e repetição. Tradução de Luiz Orlandi e Roberto Machado. Lisboa: Relógio D'Água, 2000.

DERRIDA, Jacques e BENNINGTON, Geoffrey. "Politics and friendship. A discussion with Jacques Derrida". Centre for Modern French Thought, University of Sussex, 1 December 1997. http://hydra.humanities.uci.edu/derrida/pol+fr.html.

DERRIDA, Jacques. "La différance". In: DERRIDA, Jacques. Marges de la philosophie. Paris: Éditions de Minuit, 1972a. 
DERRIDA, Jacques. "Signature événement contexte". In: DERRIDA, Jacques. Marges de la philosophie. Paris: Éditions de Minuit, 1972b.

DERRIDA, Jacques. Le monolinguisme de l'autre ou la prothèse d'origine. Paris: Éditions Galilée, 1996.

DERRIDA, Jacques. Politiques de l'amitié. Paris: Éditions Galilée, 1994.

HABERMANS, Jürgen. Racionalidade e comunicação. Tradução de Paulo Rodrigues. Lisboa: Edições 70, 2002.

HABERMAS, Jürgen. "Racionalidade do entendimento mútuo". In: HABERMAS, Jürgen. Verdade e justificação. Ensaios filosóficos. Tradução de Milton Camargo Mota. São Paulo: Edições Loyola, 2004.

ORTEGA, Francisco. Para uma política da amizade: Arendt, Derrida, Foucault. Rio de Janeiro: Sinergia; Relume Dumará, 2009.

RICOEUR, Paul. O discurso da ação. Tradução de Artur Morão. Lisboa: Edições 70, 1988.

SISCAR, Marcos. "A literatura como indesconstrutível da desconstrução". Em: SISCAR, Marcos. Jacques Derrida: literatura, política e tradução. Campinas: Autores Associados, 2012.

\footnotetext{
1 A frase, na verdade, chega-nos através de um encadeamento de atribuições: Montaigne e Nietzsche (entre outros) a atribuem a Aristóteles, tendo como fonte Diógenes Laércio. Porém, como observa Agamben (2005), trata-se de um equívoco filológico, pois, ao consultar a biografia de Aristóteles na Vida dos filósofos, de Diógenes Laércio, Agamben lê algo diferente, que dá um novo sentido à sentença: "Aquele que tem (muitos) amigos, não tem nenhum amigo". Agamben, nesse texto, esclarece as razões do equívoco e critica um "esquecimento proposital" de Derrida, que no seu Politiques de l'amitié teria ignorado a sutileza filológica em favor do projeto do livro. Contudo, me consta que Derrida está bastante ciente das sutilezas gramaticais do grego antigo: "Suivant la manière dont on écrit le $\omega$ (oméga) dans O phíloi, oudeis philos, on a affaire soit à une interjection vocative (角, esprit doux et accent circonflexe) - et c'est la lecture qui a prévalu : «O amis, point d'ami » - soit au datif d'un pronom (⿳亠丷⿵冂丶 , esprit dur, accent circonflexe et iota souscrit, hôi), et c'est la lecture qui n'a pas été retenue : "celui pour lequel des amis (pour qui il y a des amis, une pluralité ou une multitude d'amis), pour lui point d'ami »; ou encore : «à trop d'amis nul ami ». Paraphrase : celui qui a trop d'amis n'en a aucun. Ce serait en somme une thèse sur le nombre des amis, sur le nombre souhaitable des amis, et non sur l'existence ou non d'un ami en general" (DERRIDA, 1994, p. 235-236.). Inclusive, em nota, Derrida agradece a Agamben pelo auxílio, sem deixar de salientar que a minúcia filológica não altera o fundo filosófico do problema, que, como se verá, tem a ver com uma contabilidade possível no seio da amizade e no âmbito da comunidade política.

2 Ver RICOEUR (1988). De acordo com Ricoeur, toda ação, no âmbito social, pode ser lida, no que tange ao voluntário e ao involuntário, como um "texto". Assim, destaca-se da ação uma identidade narrativa, algo como uma personagem que, na práxis, exibe os caracteres de uma intenção qualquer. Isso tem implicações importantes, na medida em que, para Ricoeur, o ser se mostra na "via longa dos signos", o que já significa que a inscrição do sujeito na sociedade - o seu reconhecimento - depende de uma negociação do rol de predicados e atribuições que formam parte de sua narrativa de vida.
} 
3 É importante recordar, aqui, a incisiva crítica de Alain Badiou (1998) a respeito da filosofia política de Arendt. Badiou tenta resgatar a ideia do singular na política, afastando-o da suposta "comunidade do consenso" - esta que, a seu ver, diminui o potencial político. Na verdade, para Badiou o acontecimento político não é algo da ordem do mundo construído pelas interações humanas. A verdade do político é, para ele, relativa àquilo que, permanecendo fora do espaço do consenso público e da lógica do Estado, pode, no entanto, ter em si um valor universal. Na obra de Badiou, o sentido da política vai da verdade do acontecimento político ao confronto com a ordem da pluralidade admitida no senso-comum. O Estado, ele próprio um infinito que se projeta no tempo e no espaço das singularidades, rejeita abarcar uma diferença radical não circunscrita, e, nessa refutação, dá-se o conflito como o verdadeiro acontecimento político (a diferença). Daí, a lógica "bélica" que, para Arendt, é o não-político, parece ser, no âmbito do pensamento de Badiou, essencial e constitutiva do político, não no sentido clausewitziano de que a guerra é política por outros meios, e sim, antes, no sentido de que um conflito entre aquilo que é exterior ao Estado das coisas (status quo) e o próprio senso-comum (ou censo-comum, uma vez que existe na concepção de Estado uma componente censitária forte, na visão de Badiou).

4 Essas ideias estão presentes na Teoria da Ação Comunicativa de Habermas, especialmente no que toca à visão para o consenso através de uma comunicação orientada para o entendimento. Habermas investe na possibilidade de haver, entre os sujeitos envolvidos no acontecimento político, uma interação destinada à convergência semântico-pragmática, que, por mais que não receba a sua prova de supostos conteúdos mentais (crenças, ideologias etc.), a recebe de aspectos práticos que, no limite, nada dizem do sentido ou da razão que os sujeitos individualmente fazem de si ou das coisas, mas que demonstram efetivamente um acordo mútuo (provisório, que seja). Na pragmática universal de Habermas, a comunicação dá-se sempre como efeito de linguagem, através de estratégias que, quando mobilizadas, vão colocando os modos de ser dos sujeitos dentro da própria instauração da lógica subjacente à comunicação. Nesse sentido, é natural pensar que, de algum modo, é possível haver uma orientação prática para o consenso e para a convergência de opiniões, que, resolvidas no âmbito coletivo e calculadas em função do bem prático que trazem na sua relação lógica com os postulados racionalmente colocados para os sujeitos individualmente, promovem a sociabilidade política na qual afinal pode haver meios efetivos de consolidação da justiça, da verdade e do bem. Pode haver, então, um agir comunicativo no sentido forte, de acordo com o qual toda uma sociedade se banhará na lógica e na razão, promovendo um entendimento coletivo a respeito de um juízo, uma decisão etc. (cf. HABERMAS, 2002 e HABERMANS, 2004). Nesse sentido, a amizade, tão cara a Aristóteles e Arendt, se dilui ainda mais no pensamento habermasiano por conta de sua celebração da racionalidade comunicativa.

5 Distancio-me da visão de Francisco Ortega, para quem a concepção política de Arendt privilegia a singularidade e novas formas de subjetividade política: “[e]xistem importantes pontos de confluência entre o pensamento de Hannah Arendt e os de Foucault, Derrida ou Deleuze. Minha tese a respeito é que, no fundo, todos esses autores visam a uma alternativa política que vai além de uma política partidária e que propõe a recuperação do espaço público: a política compreendida como atividade de criação e experimentação. [...] A teoria política de Hannah Arendt representa uma tentativa de pensar o acontecimento, de afrontar a contingência, de romper e inaugurar, de recusar as imagens e metáforas tradicionais oferecidas para imaginar o político e uma vontade de agir, de transgredir e superar os limites" (ORTEGA, 2009, p. 23-24). A meu ver, a concepção arendtiana ainda está muito atada às concepções teleológicas e metafísicas da filosofia política tradicional. No contraste com Deleuze especialmente (mas também com Derrida), creio que as ideias de Arendt parecem não ter a mesma profundidade, especialmente quando se trata de avaliar a diferença em si mesma como horizonte primeiro e último do político. A inversão da transcendência e da imanência promovida por Deleuze (2000), por exemplo, não deixa muito espaço para uma concepção do político que privilegia o papel do juízo que remete ao universal. Embora Arendt de fato cogite a política como ação e performance, não resta dúvida de que sua propensão a lidar com uma esfera pública do juízo faz com que sua perspectiva perca a dimensão do singular - sobretudo o singular pré-político, o singular ainda não referenciado pela linguagem - em favor da pluralidade.

6 Optei por traduzir o neografismo différance por diferensa, pois considero que assim se preserva a mudança gráfica e a homologia fonética originais. O neografismo derridiano remete a uma diferença não diferida; não se trata de uma arqueologia da diferença (a origem das diferenças em si) ou de uma condição primordial da qual se pode recortar uma axiologia, dicotomia, tricotomia etc. quaisquer, mas sim a própria lei da diferença ou o jogo pelo qual a diferença se torna possível. Ou seja, não é o estado de coisas que precede as diferenças. A diferensa é a condição pela qual a diferença se torna possível, uma vez que é ativa, é a própria atividade de diferir. Ela não obedece a nenhuma lei prescrita, justamente porque não sabe ainda o que será a menos que seja concluída na diferença. De acordo com Derrida, a diferensa é pensada como originária apenas no sentido de que ela carrega consigo qualquer possibilidade de diferenciação (cf. DERRIDA, 1972).

7 No que toca à questão da camaradagem e a formação de uma comunidade, vale a pena a leitura integral do trabalho de Benedict Anderson (2008). Ali, compreendemos como surgem os sentimentos nacionalistas, tipicamente modernos, que instauram o páthos da comunidade civil em termos de um compartilhamento da experiência comum. Nesse sentido, como mostra Anderson, o romance e o jornal são artigos imprescindíveis, na medida em que promovem esse sentimento de simultaneidade e continuidade entre a vida dos sujeitos singulares dentro de um espaço comum e reconhecível. Novamente, estamos lidando com uma amizade política que, entre outras coisas, promove e decorre do modo pelo qual o leitor enxerga no personagem do livro (e, às vezes, em seu autor) as marcas de uma forma de vida com-sentida, isto é, sentida em comum, vivida em comum (em que pesem, é claro, as especificidades da vida de cada um deles, leitor e personagem-autor).

8 Imprescindíveis, aqui, são as colocações de Derrida em "Signature événement contexte", texto no qual Derrida basicamente sustenta que "[u]n signe écrit, au sens courant de ce mot, c'est donc une marque qui reste, qui ne s'épuise pas dans le présent de son inscription et qui peut donner lieu à une itération en l'absence et au-delà de la présence du sujet empiriquement déterminé qui l'a, dans un contexte donné, émise ou produite" (DERRIDA, 1972, p. 377). A iterabilidade característica do signo linguístico é o que permite o seu infinito deslizamento de contexto a contexto, significando coisas diferentes a cada momento. Como tal, é impossível prender o sentido a um contexto ou, ainda, deslegitimar in limine uma interpretação: uma vez aberto ao contexto, o signo faz funcionar toda uma série de conexões semióticas potencialmente ilimitada. Não há, por isso, uma arché do signo, posto que este deve ser "vazio" para poder, a cada vez, fazer o seu papel de signo. 
9 Derrida vislumbra a possibilidade de uma "democracia por vir": "The idea of a promise is inscribed in the idea of a democracy: equality, freedom, freedom of speech, freedom of the press - all these things are inscribed as promises within democracy. Democracy is a promise" (DERRIDA e BENNINGTON, 1997). Mas essa "democracia prometida" terá que ser livre de qualquer eugenia, autoctonia ou território, comportando a solidão inexorável do sujeito sem amigos, para quem toda e qualquer amizade é possível. Com isso, Derrida se aproxima bastante de Agamben, que formula a ideia de uma "comunidade que vem" inteiramente baseada na singularidade mais radical, sem destino e sem origem, livre de qualquer (pre)conceito: a singularidade qualquer, a singularidade ela mesma (cf. AGAMBEN, 1990).

\section{Abstract \\ The book comunnity: literature, difference and the politics of friendship}

ABSTRACT: This paper deals with the concept of friendship and its relations with both philosophy of politics and literature. First of all, the paper reviews some of Aristotle and Hannah Arendt's works in order to reflect upon a kind of philosophy of politics that is related to the notions of consensus and friendship in favour of a Universalist conception of politics that establishes the difference between friend and enemy in the core of the political logos. Secondly, the paper approaches Jacques Derrida's thoughts, specially those presented in his book Politiques de l'amitié, in order to consider language and the notion of difference as ways to think the aporia inherent in the relationship between friendship and politics. Finally, this work speculates on how literature can be one of the places where the politics of friendship abodes.

Keywords: Politics of friendship, Jacques Derrida, Difference, Deconstruction. 